\title{
BIBLICAL ANTHROPOLOGY AND \\ THE COSMIC CONFLICT: AN OVER- VIEW WITH DIRECTED EMPHASIS ON THE WRITINGS OF ELLEN WHITE
}

Tutsch, Cindy Ellen G. White Estate TutschC@gc.adventist.org

Date of receipt: June 2012

Date of acceptance and final version: September 2012

Abstract:

This article deals about anthropology, the human nature, in relationship with the Cosmic Conflict as is presented by Ellen White. The purpose is to have a better understanding how this conflict, which began in heaven with Satan and established on Earth according to Genesis 3, influence our nature today. In relationship with the Great Conflict between Christ and Satan, it is very important focus not only in the consequences of sin for us today, but to see the solution for this Conflict, as the Bible and Ellen White teach, which will end with the glorious coming of Jesus soon, following what Ellen White wrote about this issue.

Keywords: Anthropology, Ellen White, Cosmic Conflict 


\section{Enduring Anthropological Questions}

Philosophers and theologians from ancient desert sages to postmodern existentialists have pondered the meaning and purpose of life and humanity's state after death. The questions surrounding the origin, nature, and destiny of humanity may elicit more interest from those seeking anthropological truth than does any other topic.

Scientists (particularly in metaphysical sciences), poets, and world religion pedagogues present conflicting answers to the great questions of human origins, purpose and destiny. However all human explanations must of necessity be theoretical and speculative, since no living person on earth can provide proof that he or she has experienced cognition before conception, or after death.

\section{God's Word Provides Authoritative Answers}

The Incarnate Christ not only lived on earth (John 1:14, 14) and entered the mysterious sphere of death, but also rose from the dead (Rom 6:9) to life "original, unborrowed, underived," (Whi- te, 1898 , p. 530). Possessing the keys to experiential knowledge of life (John 11:25), death (Rev 1:1718 ), and humanity's purpose (Eccl 12:13; Eph 1:4, 5; Eph 2:10), He chooses to reveal His anthropological wisdom through heavenly messengers who spoke to human agents (Rev 1:1-2). These agents transcribed heaven's messages into the words of humanity (1Pet 1:20-21), which eventuated in the Scriptures, the God-breathed Word (2Tim 3:16). Thus, for the Christian, biblios provides authoritative answers to the grand cosmological questions.

The God of truth reveals the deep and secret things (Dan 2:22). This wisdom, this truth, is not composed of dead letters; it is spirit (John 6:63) and living energy (Heb 4:12). Human thought, reason, scientific demonstration, creedal statements-all must bow in submission to God's Word, and become subordinate to its verity.

\section{Cosmic Significance of Lu- cifer and Christ in Conflict}

Seventh-day Adventists place the cosmic conflict between Christ and Satan at the core of understanding suffering, pain, di- 
saster and death on Planet Earth. This conflict is the lens through which human history, purpose, and future is understood. Ellen White understood both Ezek 28 and Isa 14 to present a narrative of the rebellion of Lucifer. Though most expositors of the reformation period argued against Isa 14 referring to Satan, early church fathers such as Origen, Augustine, Gregory the Great, Peter Lombard, and Thomas Aquinas believed verses 13, 14 referenced Satan. Modern theologians Gregory Boyd, William Dembski, and others-believe both Isa 14 and Ezek 28 have application to Satan. ${ }^{1}$

Descriptors of the king of Babylon must go beyond local application since a Babylonian king had never been in heaven nor had the king of Tyre lived in Eden's Garden or been a covering cherub. "In both passages the kings were cast out of heaven because of pride (Isa 14:12, 15; Ezek 28:16-17). The king of Tyre is said to have been perfect until sin was found in him (Ezek 28:15), which can-

1 G. A. Boyd, God at War: The Bible and Spiritual Conflict (Downers Grove, IL: InterVarsity Press, 1997), 157-62; W. A. Dembski, The End of Christianity: Finding a Good God in an Evil World (Nashville, TN: B \& H Academic, 2009), 134-35. not be said of any human since the Fall (Rom 5:16-18).2 Lucifer, chief of God's angelic host, harboring rebellion against God, aspired to become as God, and even to usurp His position: "I will ascend to heaven; I will raise my throne above the stars of God; I will sit enthroned on the mount of assembly, on the utmost heights of the sacred mountain. I will ascend above the tops of the clouds: I will make myself like the most High" (Isa 14:13, 14).

God pleaded long with Lucifer, presenting "before him the greatness, the goodness, and the justice of the Creator, and the sacred, unchanging nature of $\mathrm{His}$ law"3 Again and again, Lucifer was offered pardon, and had he repented, God would have reinstated him to his position as chief of the celestial angels. ${ }^{4}$

Abusing the freedom God gave to His created beings, Lucifer persisted in his envy, rebellion, and desire for predominance. God describes Lucifer's state with this lamentation: "Thus says the Lord

2 N. R. Gulley, "Why is God so Misunderstood?" Ministry, December 2011, 22.

3 E. G. White, The Desire of Ages (Mountain View, CA: Pacific Press, 1898), 494.

4 Ibíd., 496. 
God: 'You were the seal of perfection. Full of wisdom and perfect in beauty. You were in Eden, the garden of God; Every precious stone was your covering... The workmanship of your timbrels and pipes was prepared for you on the day you were created. You were the anointed cherub who covers; I established you; You were on the holy mountain of God: You walked back and forth in the midst of fiery stones. You were perfect in your ways from the day you were created, Till iniquity was found in you" (Ezek 28:12-15 NKJV).

"[Lucifer] gloried in his brightness and exaltation and aspired to be equal with God. He was beloved and reverenced by the heavenly host, angels delighted to execute his commands, and he was clothed with wisdom and glory above them all. Yet the Son of God was exalted above him, as one in power and authority with the Father. He shared the Father's counsels, while Lucifer did not thus enter into the purposes of God. 'Why,' questioned this mighty angel, 'should Christ have the supremacy? Why is He honored above Lucifer?"

5 E. G. White, The Great Controversy Between Christ and Satan: The Conflict of the Ages in the Christian Dispensa-

\section{Conflict in Heaven}

Lucifer exploited his influence as chief of heaven's creation to infect his dissatisfaction about God among the angelic host. His power to deceive was enormous as he disguised his purpose in a cloak of falsehood (2 Cor 11:13-14). Pretending to have the best interest of the angelic hosts at heart, Lucifer at first seemed noncommittal. "All his acts were so clothed with mystery that it was difficult to disclose to the angels the true nature of his work. Until fully developed, it could not be made to appear the evil thing it was; his disaffection would not be seen to be rebellion. Even the loyal angels could not fully discern his character or see to what his work was leading". ${ }^{6}$ Lucifer used what God could not - flattery and deceit $-^{7}$ to distort the truth about God's omniscience.

God could have easily destroyed Lucifer, but He did not. "God in His wisdom permitted [Lucifer] to carry forward his work, until the spirit of disaffection ripened into active revolt. It was necessary for his plans to be fully developed, tion (Mountain View, CA: Pacific Press, 1911), 37.

6 E. G. White, Patriarchs and Prophets (Mountain View, CA: Pacific Press, 2005), 41.

7 Ibíd., 42. 
that their true nature and tendency might be seen by all". ${ }^{8}$ Had Lucifer been immediately annihilated, created beings would have served God from fear, rather than from willing hearts.

\section{Lucifer Cast Out of Heaven to Earth}

The ensuing revolution culminated in actual war in heaven (Rev 12:7-9) with the inference of one third of the celestial beings joining the insurgency. "Cast down to earth" (Rev 12:4, Luke 10:18, Jude 1:6), Lucifer now became Satanas, the avowed adversary of God and the slanderer of His character of love. Thus Lucifer formed himself into a god of his own making, "the father of lies" (John 8:44), and prepared to beguile God's newest creation.

\section{God's Purpose for Humanity's Creation}

After speaking the earth and all non-human life into existence (Ps 33:6, 9; Ps 104:5), the triune God (Gen 1:26) established His divine purpose for His creation by forming the man and woman in His own image (Gen 1:27), only "little lower than the angels" (Ps

8 White, The Great Controversy, 497.
8:5). God created the earth to be inhabited (Isa 45:18) by pure and holy beings with whom He could enter into close relationship and communication. God's intention was that the likeness of His character of righteousness and purity would be revealed in His children, and that the earth would be peopled with happy and holy friends after His own heart (Gen 1:28). "The genealogies in Genesis demonstrate that the successive generations after Adam and Eve all descended from this first pair. Paul said, 'From one man he [God] made every nation of men, that they should inhabit the whole earth.' Acts 17:26, NIV".

"You made us only a little lower than God" (Psalm 8:5 NLT) seems to introduce a new reason for Satan's attack on monism and ultimately, on God Himself. This translation seems to describe a new order of being. Could it be possible that "humanity" is different from any previous order of creation? If humanity is created "a little lower than God," where does that place an angel in the hierarchy of the universe? What an-

9 Ministerial Association General Conference of Seventh-day Adventists, Seventh-day Adventists Believe: A Biblical Exposition of Fundamental Doctrines, 2nd ed. (Silver Spring, MD: Author, 2005), 93. 
gel did God ever make "ruler" of a new planet-to have dominion over it? Is it possible Lucifer saw himself as not only subordinate to Christ, but now also, in a sense, subordinate to the new order of creation, humanity?

Perhaps we could expand Satan's statement to "I will ascend-not only above this new 'kind' of God's creation-but even above God Himself." Could this have heightened his appeal to other angels? They might have reasoned, "We are only messengers, servants, ministering spirits. We've worked eons for God, and now, rather than promoting from within, God has created a whole new race who we must also serve. We are nothing but slaves (doulos)!" (This accusation, if plausible, could account in part for Christ's voluntarily incarnation to "servant slave.")

If this scenario is feasible, then dualism becomes a necessary lie not only to deceive Eve and her descendants, but also to sustain Satan's usurped position. Lucifer knew that God is the source of all life and the sole source of immortality. Lucifer had, then, to "invent" dualism to vest himself with immortality in order to "ascend above God."

\section{The Impact of Dualism}

Classical dualism stems largely from the writings of Plato, Aristotle, and the Stoics and defines death as the separation of the soul from the body. Implications from dualism emerge that impact the moment of death, humanity's state in death, the resurrection, the final punishment, and the world to come.

Thus, the dichotomy of Platonic dualism has negative implications for Christian spirituality, soteriology, and eschatology. However, dualism also impacts what we believe about our present life, particularly fostering negative views of the body in contrast with the positive role of the soul. Redemption then becomes only an internal experience of the soul as opposed to a complete transformation of the whole person..$^{10}$

Many belief systems are derived from anthropological dualism. Consider the intercessory roles of Mary and the saints or popular beliefs about paradise, purgatory, hell-all unsupported by biblical exegesis of mortality. Since Plato considered material components of earth to be evil, the Christian's

10 Samuel Bacchiocchi, Immortality or resurrection: A biblical study on human nature and destiny (Berrien Springs, MI: Biblical Perspectives, 1998), 17. 
hope of ultimate restoration of creation and its creatures (Rom $8: 19-23)$ is reduced to some sort of eternal, ethereal contemplation in a spiritualized heavenly state.

"Conversely, when Christians view themselves and the present world wholistically as the object of God's good creation and redemption, they will be ... compelled to act as God's steward of their bodies as well as of the created order". ${ }^{11}$ Thus, "Issues of social justice, war, racism, poverty, and economic imbalance should be of concern to those who believe that God is working to restore the whole person and the whole world". 12

In addition to the dualism inherent in the doctrine of the immortal soul, some since the Enlightenment have defined humanity as only a cog in the universal cosmic machine. Though this view does not propagate the dualistic view of a present immortal soul, neither does it offer hope, since humans exist only in a mechanistic universe whose behavior is driven by involuntary forces. According to anthropic mechanists, humanity cannot ever possess immortality. ${ }^{13}$

11 Ibíd., 34.

12 Ibíd.

13 "Although starting from diffe-

\section{The Nature of Humanity}

What is believed about human nature significantly impacts what is believed about human destiny. In contrast to dualism, the holistic or monistic nature conferred on Adam and subsequent humanity is three fold, comprised of physical, intellectual, and moral powers. God intended that these powers be cultivated and developed, that each individual would maintain accountability to himself or herself, to society, and to God." ${ }^{14}$ Today, "[All] should understand the functions of the various organs and the dependence of one upon another for the healthy action of all. They should Malebranche and the pre-established harmony of Leibniz agree in denying all relation between the soul and body and in explaining their union in man by a dualistic parallelism. The second explanation, furnished by Spinoza, rejects the miraculous and transcendental intervention of God, identifying thought with God Himself, who is the only substance. This is why, by contrast with the first, we call it a monistic parallelism". J. R. Zurcher, The Nature and Destiny of Man: Essay on the Problem of the Union of the Soul and the Body in Relation to the Christian Views of Man (New York, NY: Philosophical Library, 1969), 59.

14 E. G. White, Child Guidance: Counsels to Seventh-day Adventist Parents (Hagerstown, MD: Review \& Herald, 2002), 39. 
study the influence of the mind upon the body and of the body upon the mind, and the laws by which they are governed". ${ }^{15}$

In her treatment of the nature of man, Ellen White departs from the Greek philosophy that separates mind, spirit, and body. Though Paul sometimes uses philosophical terms in writing of the nature and mortality of humanity, he writes through the lens of a Hebrew, not Hellenistic, worldview. Thus he speaks of the nature of humanity as being whole, never disconnected. Ellen White is also clear in this integration of mind, spirit, and body.

Biblical wholism sees both body and soul as a perdurable unit. Because the body is the temple of the Holy Spirit (1 Cor $6: 18$ ), both the spiritual needs of the soul and physical needs of the body must be equally maintained.

\section{The Entrance of Sin and Genesis 3:15}

Satan determined to ruin the tranquility and joy of God's newest children in Eden. Though created innocent and holy as a personal

15 E. G. White, Ministry of healing (Mountain View, CA: Pacific Press, 1905), 128. act of God's love, Adam and Eve "were not placed beyond the possibility of wrongdoing. God made them free moral agents, capable of appreciating the wisdom and benevolence of His character and the justice of His requirements, and with full liberty to yield or to withhold obedience". ${ }^{16}$ The tree of knowledge, growing near the tree of life in the middle of their garden home, was to be the test of their fidelity and loyalty to God, their Creator. ${ }^{17}$ Of all that was in their garden home, only the fruit of the tree of knowledge of good and evil was forbidden to them. They could obey and enjoy their Eden home forever, or they could disobey, bringing misery, ruin, and ultimately, death. ${ }^{18}$

Envious of Adam and Eve's happiness and peace, Satan plotted to cast dishonor upon God, and cause grief in heaven by inciting the holy pair to disobedience. Though warned of the arch deceiver's potential to deceive, tempt, and destroy, Eve nonetheless succumbed to the wily foe's flattery as spoken through the serpent, and ate from the forbidden tree (Gen 3:1-6). Satan had succeeded in causing Eve to doubt God's love and wisdom.

16 White, Patriarchs and prophets, 48. 17 Ibíd., 48-49.

18 Ibíd., 53. 
"Eve really believed the words of Satan, but her belief did not save her from the penalty of sin. She disbelieved the words of God, and this was what led to her fall". 19

Perceiving no immediate sense of death or dying, Eve then became the agent of Satan in accomplishing the ruin of her husband, who ate of her proffered fruit (Gen 3:6). ${ }^{20}$ Because of their sin, (and the subsequent sins of every descendant of Adam), the sentence of death was pronounced on all of humanity (Rom 6:23). Thus, death is a direct consequence of sin and was first introduced to Planet Earth through disobedience. Pain, suffering, death and natural evil are not normal instrumentalities through which God creates or for which $\mathrm{He}$ is responsible. By choosing to accept Lucifer's lies against God's plain directives, earth's first parents separated themselves from Christ, the source of life.

In consequence of their rebellion against God and His government, Adam and Eve and their descendants were barred from their Eden home. "The dominion of this earth passed under the sway of a new ruler. Satan

19 Ibíd., 55.

20 Ibíd., 56. took Adam's place as the governor of the planet, and the human race passed under his [usurped] dominion. He now became the 'god of this world' (2 Corinthians 4:4)" ${ }^{21}$ Hence, disease, disaster, and death are brought by Satan. ${ }^{22}$

\section{Perpetuity of the Law of God}

"To Eve it seemed a small thing to disobey God by tasting the fruit of the forbidden tree, and to tempt her husband also to transgress; but their sin opened the floodgates of woe upon the world". ${ }^{23}$ "Many who teach that the law of God is not binding upon man, urge that it is impossible for him to obey its precepts. But if this were true, why did Adam suffer the penalty of transgression? The sin of our first parents brought guilt and sorrow upon the world, and had it not been for the goodness and mercy of God, would have plunged the race into hopeless despair". ${ }^{24}$

Though the right to eat from the tree of life was taken away from Adam and Eve (Gen 3:22),

21 C. B. Haynes, Life, Death, and Immortality (Nashville, TN: Southern, 1952), 59.

22 White, The desire of ages, 590-91. 23 White, Patriarchs and prophets, 61 . 24 Ibíd. 
God would not abandon His children to perpetual suffering and eternal death. On the very day that their dominion was lost, God called the guilty pair from their hiding place in the garden and offered them hope regarding the possibility of total reconciliation with God and restoration of all that they had lost. "The instant man accepted the temptations of Satan, and did the very things God had said he should not do, Christ, the Son of God, stood between the living and the dead, saying, 'Let the punishment fall on Me. I will stand in man's place. He shall have another chance"”. ${ }^{25}$

The implication of a Messiah to come can be found in the irrevocable sentence God pronounced upon the serpent in consequence of his deception: "And I will put enmity between you and the woman, between your seed and her Seed; He shall bruise your head, and you shall bruise His heel" (Gen 3:15, NKJV).

These words of divine judgment apply not only to the serpent, the medium through which

25 F. D. Nichol y M. L. Andreasen, eds., The Seventh-day Adventist Bible Commentary: The Holy Bible with Exegetical and Expository Comment (Washington, DC: Review \& Herald., 1953), 1:1085. the temptation emanated, but also to Satan, pointing to his ultimate defeat and destruction. ${ }^{26}$ Even before the creation of the earth, the plan of salvation through the vicarious death of Christ had been laid (Rev 13:8). "The broken law of God demanded the life of the sinner. In all the universe there was but one who could, in behalf of man, satisfy its claims. Since the divine law is as sacred as God Himself, only one equal with God could make atonement for its transgression. None but Christ could redeem fallen man from the curse of the law and bring him again into harmony with Heaven". ${ }^{27}$ Sin is humanity's utter estrangement from God, which could be healed only by one who is outside the stream of human history. Death is the consequence of sin, and only God Himself could pay the price of sin for all of humanity.

In the words of Gen 3:15, Satan recognized not only judgment of himself and a prediction of his ultimate loss of earthly dominion followed by his demise, but also the promise of Divine intervention in human history. Thus he would spend the next millennia attempting to thwart the purposes of

26 White, Patriarchs and prophets, 58. 27 Ibíd., 63. 
God regarding the redemption of the race. Notwithstanding Satan's rage, "by repentance toward God and faith in Christ the fallen children of Adam might once more become 'children of God.' 1 John 3:2." The promise of "enmity between thy seed and her seed" meant God would provide grace and strength to those who longed to resist Satan's power, abhor sin, and conquer the temptation to do evil. Thus, in contrast with dualism, immortality was not innate at creation, but rather a gift to be ultimately received by those who would be saved through faith in Christ.

\section{Humanity and Immortality}

Adam and Eve were immortal only as they continued to partake of the tree of life. Barred from its fruit, the warning "you will surely die" (Gen 2:17) became a grim reality. At his creation in Eden, Adam was perfectly formed, but lifeless until God "breathed into his nostrils the breath of life; and man became a living soul [or being)" (Gen 2:7). This "breath of life" combined with the body (the dust of the ground) comprises a living person. When a person ceases altogether to breathe, life stops. There is no indication in Gen 2:7-or elsewhere in Scripture-that God gave Adam a spiritual essence that lives independently, outside of the body, after the individual ceases breathing and dies. Thus, consciousness is a combination of the "dust of the ground," or body, and the God-originating "breath of life; it is dependent on the union of the breath with the body. Continuance of life is sustained only by God. When the breath of life departs, there is utter extinction of life.

Satan had attempted to incite distrust of God's plain declaration that the first pair would surely die if they ate of the forbidden fruit by pointing out (through the serpent medium) that he had eaten the fruit and yet still retained life and vigor. Thus his first temptation to humanity centered in the idea of immortality apart from God. This revision of God's Word regarding humanity's state in death would remain one of Satan's primary deceptions throughout the course of earth history. Though today Christian mortalists are increasing in number, the belief that the souls of the righteous ascend immediately to heaven and the souls of the unsaved go somewhere else "has defined and undergirded Christianity for at least 1,000 
years" ${ }^{28}$ Making a distinction between body and soul may have originated in Oriental philosophy, but early Greek philosophers developed dualism into what would become the dominant worldview. "Platonic dualism infiltrated the medieval church, resulting in the doctrine of purgatory that was built on the foundation of the immortal soul and eventually came to dominate medieval eschatology". 29 "The divine sentence, "The soul that sinneth, it shall die' (Ezek 18:20) is made to mean: The soul that sinneth, it shall not die, but live eternally". ${ }^{30}$

\section{Death, Resurrection and the Eschaton}

Christ only possesses immortality (2 Tim 6:16) and He gives it to the righteous who are redeemed at His second coming, a view sometimes described as conditional immortality (1 Cor 15:51-54). Death is represented by Christ as a sleeplike state (John 11:11-14), void of thought or consciousness. At the eschaton, the righteous are raised from their graves to life eternal with Christ. The righteous who

28 B. W. Ball, "The immortality of the soul: Could Christianity survive without it? Part 1," Ministry, March 2011, 10.

29 Ibíd.

30 White, The desire of ages, 533. are living when Christ returns join those who are resurrected to meet the Lord in the air "and thus shall we always be with the Lord" (1 Thess 4:16, 17).

"The Scriptures never use language comparable to that found on memorial gravestones or heard in many funeral sermons. In these it is taught that all that is mortal of the deceased lies in the grave, but he himself has gone elsewhere. In Scripture, the person, the individual, the man, he who was once alive and is now dead, is always spoken of as lying in the grave". ${ }^{31}$

Though Scriptures do not support the doctrine of purgatory, eternal torment, or the soul's immortality, neither do they support universalism.

"[A large class] see that the Scriptures represent God as a being of love and compassion, and they cannot believe that $\mathrm{He}$ will consign His creatures to the fires of an eternally burning hell. But holding that the soul is naturally immortal, they see no alternative but to conclude that all mankind will finally be saved. ... Such a doctrine, presuming upon God's mercy, but ignoring His justice, pleases the carnal heart and emboldens the wicked

31 Haynes, 45 . 
in their iniquity" 32

God's character of love is also maligned through Satan's first and on-going deception regarding the state of humanity in death. "Upon the fundamental error of natural immortality rests the doctrine of consciousness in death-a doctrine, like eternal torment, opposed to the teachings of the Scriptures, to the dictates of reason, and to our feelings of humanity". Soul consciousness also reduces anticipation for the biblically-based doctrine of the eschaton and concurrent resurrection of the righteous dead. If the souls of the dead already enjoy the glories of heaven, why would the second coming of Christ to earth hold significance?

Paul said, "For if the dead do not rise, then Christ is not risen. And if Christ is not risen, your faith is futile; you are still in your sins! Then also those who have fallen asleep in Christ have perished" (2 Cor 15:16-18 NKJV). "If for four thousand years the righteous had gone directly to heaven at death, how could Paul have said that if there is no resurrection, 'they also which are fallen asleep in Christ are perished?' No resurrection would be

32 White, The Great Controversy, 537. necessary". 33 When Christ assured His disciples that He would return for them (John 14:13), He said nothing about them coming soon to Him in heaven. Rather, Paul established the chronology of reunion with Christ in 1 Thess 4:16-18: "The Lord Himself shall descend from heaven with a shout, with the voice of the Archangel, and with the trump of God: and the dead in Christ shall rise first: then we which are alive and remain shall be caught up together with them in the clouds to meet the Lord in the air: and so shall we ever be with the Lord."

"Before any can enter the mansions of the blessed, their cases must be investigated, and their characters and their deeds must pass in review before God. All are to be judged according to the things written in the books and to be rewarded as their works have been. This judgment does not take place at death". ${ }^{34}$ Paul corroborates this: "Because He has appointed a day on which He will judge the world in righteousness by the Man whom He has ordained. He has given assurance of this to all by raising Him from the dead" (Acts 17:31). Jude also references a future day of judgment:

33 Ibíd., 546-47.

34 Ibíd., 548. 
"And the angels who did not keep their proper domain, but left their own abode, He has reserved in everlasting chains under darkness for the judgment of the great day" (Jude 1:6). If the dead were already in the bliss of heaven or in the punishment of hades, why would there be a necessity for a future judgment?

Another serious charge against the heresy of the soul's immortality is that it undermines the redemptive work of Christ. ${ }^{35}$ In debating the cosmological significance of 1 Cor 15 and 1 Thess 4 with Sir Thomas More, the English reformer William Tynda-

"Nay Paul, thou art unlearned, go to Master More and learn a new way. We be not most miserable, though we rise not again, for our souls go to heaven as soon as we be dead, and are there in great joy as Christ that is risen again. And I marvel that Paul had not comforted the Thessalonians with that doctrine, if he had wist it, that the souls of their dead had been in joy, as he did with resurrection, that their dead should rise again. If the souls be in heaven in as great glory as the angels, after your doctrine, shew me what cause should

35 Ball, 10.

be of the resurrection?" ${ }^{36}$

Peter Peckard expands that argument: "Jesus Christ came into the world on purpose to redeem men from death and to give them life and immortality. It is very certain that he could not redeem them from that state in which they were not, nor give them that life and immortality which they already possessed. So that by this scheme [the natural immortality of the soull the whole notion of redemption by Jesus Christ is absolutely and entirely destroyed". ${ }^{37}$

Though most Christians today hold to the view of the soul's immortality, increasingly theologians and scholars are challenging that eschatology. I cite only two modern examples: William Temple, archbishop of York and later Canterbury, wrote, "Man is not by nature immortal, but capable of immortality. [The] prevailing doctrine of the New Testament is that God alone is immortal ... and 36 W. Tyndale, An Answer unto Sir Thomas More's Dialogue: The Supper of the Lord After the True Meaning of John VI and 1 Cor. XI. and Wm. Tracy's Testament expounded in the works of the English reformers: William Tyndale and John Frith, ed. T. Russell (London: Ebenezer Palmer, 1831), 11:123.

37 P. Peckard, Observations on the Doctrine of an Intermediate State Between Death and the Resurrection (London: Davis \& Reymers, 1756), 4. 
He offers immortality to man not universally but conditionally". ${ }^{38}$

More recently, renowned evangelical author N. T. Wright says, "At least since the Middle Ages the influence of Greek philosophy has been very marked, resulting in a future expectation that bears far more resemblance to Plato's vision of souls entering into disembodied bliss than to the biblical picture of new heavens and new earth". ${ }^{39}$ Indeed, it does seem to be a strange contortion of Scripture that requires death to actually mean life-somewhere-heaven, hell, or in between!

\section{Satan's Final Delusions}

The father of lies has been honing his deceptions regarding human origins and destiny for thousands of years, preparing for the final conflict that plunges humanity into chaos and choices of desperation just preceding the eschaton. Ellen White writes:

38 W. Temple, Nature, Man, and God: Being the Gifford Lectures Delivered in the University of Glasgow in the Academical Years, 1932-1933 and 19331934. (London: Macmillan, 1934), 30: 461-63.

39 N. T. Wright, Surprised by Hope: Rethinking Heaven, the Resurrection, and the Mission of the Church (New York, NY: HarperCollins, 2008), 80.
"If the dead are admitted to the presence of God and holy angels, and privileged with knowledge far exceeding what they before possessed, why should they not return to the earth to enlighten and instruct the living? ... How can those who believe in man's consciousness in death reject what comes to them as divine light communicated by glorified spirits? Here is a channel regarded as sacred, through which Satan works for the accomplishment of his purposes. The fallen angels who do his bidding appear as messengers from the spirit world. While professing to bring the living into communication with the dead, the prince of evil exercises his bewitching influence upon their minds". ${ }^{40}$

As part of his façade near the consummation of earth history, Satan attempts to embrace the entire world in his confederacy. "Hiding his deformity under the garb of Christianity, he assumes the attributes of a Christian, and claims to be Christ Himself'. ${ }^{41}$

Apparently, this deception will

40 White, The Great Controversy, 551.

41 E. G. White, Manuscript Releases from the Files of the Letters and Manuscripts Written by Ellen G. White (Washington, DC: E. G. White Estate, 1981), 8:346. 
be so overpowering that "if it were possible, they shall deceive the very elect" (Matt 24:24). The implication is that even God's faithful remnant would find it difficult to discern the counterfeit because it so closely resembles the true. "As the spirits will profess faith in the Bible and manifest respect for the institutions of the church, their work will be accepted as a manifestation of divine power" 42

Ellen White's comments are instructive regarding how this deception could overcome even Seventh-day Adventists:

"We have far more to fear from within than from without. The cess are far greater from the church itself than from the world... The unbelief indulged, the doubts expressed, the darkness cherished, encourage the presence of evil angels, and open the way for the accomplishment of Satan's devices". 43

"The saints must get a thorough understanding of present truth, which they will be obliged to maintain from the Scriptures. They must understand the sta42 White, The Great Controversy, 588. 43 E. G. White, Selected Messages from the Writings of Ellen G. White (Hagerstown, MD: Review \& Herald, 2006), 1:122.

te of the dead, for the spirits of devils will yet appear to them, professing to be beloved friends and relatives, who will declare to them that the Sabbath has been changed, also other unscriptural doctrines". ${ }^{44}$

Occult and communicationwith-the-dead themes saturate today's entertainment media. Movies, music, popular literature, sit-coms, TV drama, Broadway, and video games-in a thousand forms, Satan attempts to make other world communication enticing and credible. Even an unnamed journalist in People magazine questioned the trend: "What is it with the dearly departed? Seems they're everywhere lately. Ghosts, ghouls and spirits are invading prime time....".

But these are only preambles to Satan's deceptions regarding mortality:

"Wonderful scenes, with which Satan will be closely connected, will soon take place. God's Word declares that Satan will work miracles. He will make people sick, and then will suddenly remove from them his satanic power. They will then be regarded as 44 E. G. White, Last Day Events: Facing Earth's Final Crisis (Nampa, ID: Pacific Press, 2000), 156.

45 "They See Dead People," People, November 7 2005, 91. 
healed. These works of apparent healing will bring Seventh-day Adventists to the test". ${ }^{6}$

"Through the two great errors, the immortality of the soul and Sunday sacredness, Satan will bring the people under his deceptions. While the former lays the foundation of spiritualism, the latter creates a bond of sympathy with Rome". 47

Various individuals will impersonate Christ, perform supernatural acts of healing, and claim to have messages from heaven that are not in harmony with the Word of God. But those who have fortified their minds with the truths of Scripture will recognize the deception. ${ }^{48}$

"The people of God will not be misled. The teachings of this false christ are not in accordance with the Scriptures. His blessing is pronounced upon the worshipers of the beast and his image, the very class upon whom the Bible declares that God's unmingled wrath shall be poured out". ${ }^{49}$

46 White, Selected Messages, 2:53.

47 White, The Great Controversy, 588.

48 Ibíd., 593-94; White, Last Day Events: Facing Earth's Final Crisis, 157.

49 White, The Great Controversy, 624-25.
At this time, false revivals will break out in those churches which have redirected emphasis from the authority of the Word of God to an emphasis on experience, reader-response, or tradition, especially regarding the Sabbath and soul immortality.

"Before the loud cry of the third angel is given, [Satan] raises an excitement in these religious bodies, that those who have rejected the truth may think that God is with them". ${ }^{50}$ It will appear as though the Spirit is working powerfully, which causes a "3rd Wave" of religious interest. But emotional charisma notwithstanding, "wherever men neglect the testimony of the Bible, turning away from those plain, soul-testing truths which require self-denial and renunciation of the world, there we may be sure that God's blessing is not bestowed". 51 "God's work is ever characterized by calmness and dignity". 52

Even music can become an agency of deception and counterfeit revival. "Satan will make music a snare by the way in which it is conducted". ${ }^{53}$ Beautiful pra-

50 E. G. White, Early Writings (Hagerstown, MD: Review \& Herald, 2000), 261.

51 White, The Great Controversy, 464. 52 White, Selected Messages, 2:42.

53 Ibíd., 2:36, 38. 
yers and articulate sermons, even those sermons which ostensibly promote Christ, could be a baited trap if the Word of God is contradicted or demythologized. "Not everyone who says to Me, 'Lord, Lord,' will enter the kingdom of heaven; but he who does the will of My Father who is in heaven" (Matt 7:21). "The most profitable meetings for spiritual advancement are those which are characterized with solemnity and deep searching of heart, each seeking to know himself and, earnestly and in deep humility, seeking to learn of Christ". 54

\section{God Prepares the Remnant for Extremity}

The people of God will be genuinely spiritually renewed as an outcome of a revival of "primitive godliness". ${ }^{5}$ Joel 2:28-29, Hos 6:3, and Zech 10:1 may describe a special outpouring of the Holy Spirit in an event Ellen White calls "The Latter Rain." "The outpouring of the Spirit in the days of the apostles was the 'former rain,' [Pentecost] and glorious was the result. But the latter rain will

54 E. G. White, Testimonies for the Church, 4th ed. (Mountain View, CA: Pacific Press, 2007), 1:41.

55 White, Last Day Events: Facing Earth's Final Crisis, 158. be more abundant". ${ }^{56}$ It revives and strengthens God's people to pass through the time of trouble, ${ }^{57}$ and gives power to their witness, enabling them to give the loud cry-the proclamation of God's character of love and His call to come out of mystical Babylon (Rev 18:1-5).

As chaos and catastrophes inrush just before the eschaton, religious leaders will urge politicians and governments to enforce Sunday observance, ostensibly to improve the morals of society. ${ }^{58}$ "As America, the land of religious liberty, shall unite with the papacy in forcing the conscience and compelling men to honor the false Sabbath, the people of every country on the globe will be led to follow her example".59 Satan now pulls out all his stops ${ }^{60}$-even appearing to bring fire down from heaven (Rev 13:13) ${ }^{61} \quad$-endeavoring through every deceptive means to 56 White, Testimonies for the Church, 8:21.

57 Ibíd., 1:353.

58 White, The Great Controversy, 587.

59 White, Testimonies for the Church, 6:18.

60 E. G. White, Testimonies to Ministers and Gospel Workers (Mountain View, CA: Pacific Press, 1962), 411.

61 E. G. White, Medical Ministry: A Treatise on Medical Missionary Work in the Gospel (Nampa, ID: Pacific Press, 2003), 87-88. 
compel obeisance to Sunday, the spurious sabbath. When Sundaykeeping is enforced by universal law, two opposing marks will be given. Those who are loyal to God receive His seal, those who observe the false sabbath, an institution of the papacy, receive the mark of the beast (Rev 7:3; Rev 9-10). ${ }^{62}$

The warfare between the two great opposing powers will be intense.

"Evil angels in the form of men will talk with those who know the truth. They will misinterpret and misconstrue the statements of the messengers of God. ... Have Seventh-day Adventists forgotten the warning given in the sixth chapter of Ephesians? We are engaged in a warfare against the hosts of darkness. Unless we follow our Leader closely, Satan will obtain the victory over us". ${ }^{63}$

Daniel 12:1 states that there will be a time of distress such has never occurred since there was a nation, but everyone who is found written in the book will be rescued. Ellen White describes that last spiritual conflict:

"A terrible conflict is before us.

We are nearing the battle of the

62 White, The Great Controversy, 605.

63 White, Selected Messages, 3:411. great day of God Almighty. That which has been held in control is to be let loose. The angel of mercy is folding her wings, preparing to step down from the throne and leave the world to the control of Satan. The principalities and powers of earth are in bitter revolt against the God of heaven. They are filled with hatred against those who serve Him, and soon, very soon, will be fought the last great battle between good and evil. The earth is to be the battle field-the scene of the final contest and the final victory. Here, where for so long Satan has led men against God, rebellion is to be forever suppressed". ${ }^{64}$

\section{The Counterfeit Coming of Christ}

"As the crowning act in the great drama of deception, Satan himself will personate Christ. [though he is not permitted to counterfeit the coming of Christ in the clouds, witnessed by the whole world"]. ${ }^{65}$ The church has long professed to look to the Saviour's advent as the consummation of her hopes. Now the great deceiver will make it appear that Christ has come. In different

64 E. G. White, "Neglected duties," Review \& Herald 79, no. 19 (1902): 9.

65 White, The Great Controversy, 625. 
parts of the earth, Satan will manifest himself among men as a majestic being of dazzling brightness, resembling the description of the Son of God given by John in the Revelation (Rev 1:13-15). The glory that surrounds him is unsurpassed by anything that mortal eyes have yet beheld. The shout of triumph rings out upon the air: "Christ has come! Christ has come!" ${ }^{66}$

Healing the diseases of the people, Satan, now disguised as Christ Himself, speaks many of His same gracious truths. Around the globe, masses adore the counterfeit of society to appease a seemingly angry god, the counterfeit Christ claims to have changed Sabbath to Sunday, and commands everyone to observe the day he has blessed. "This is the strong, almost overmastering delusion". 67

Yet, there will be one clear distinction between the words of Christ and the words of His counterfeit: Satan will attempt to turn the people from the law of God. ${ }^{68}$

66 White, Last Day Events: Facing Earth's Final Crisis, 163.

67 White, The Great Controversy, 624.

68 E. G. White, Fundamentals of Christian education (Nashville, TN: Southern, 1992), 471-72.

"Notwithstanding this, so well will he counterfeit righteousness that, if it were possible, he would deceive the very elect. Crowned heads, presidents, rulers in high places, will bow to his false theories". ${ }^{69}$

From the beginning of his rebellion in heaven, Satan has endeavored to prove that the law of God is arbitrary and impossible to keep.

Thus all his pent-up rage is vented on a remnant who hold God's law as sacred, especially the controverted fourth commandment (Rev 12:17).

\section{Opportunity to Choose Christ Ceases}

Before the seven last plagues fall on the impenitent, the opportunity to make a decision for Christ ceases (Rev 15:8; Rev 22:11). ${ }^{70}$ Jesus leaves His intercession in the Most Holy Place. ${ }^{71}$

"When probation ends, it will come suddenly, unexpectedly-at a time when we are least expecting it. But we can have a clean record in heaven today, and know that God accepts us". 72

69 Ibíd.

70 Nichol y Andreasen, eds., 7:976.

71 White, The Great Controversy, 613. 7:989.

72 Nichol y Andreasen, eds., 
When the whole world wonders after the beast (Rev 13:3) and chooses the authority of Satan over God by observing Sunday, the faithful remnant who remain loyal to God's commandments will be persecuted, harassed, forbidden to buy or sell (Rev 13:17), and given civil penalties. ${ }^{73}$ Ultimately, the death penalty will be decreed against those who observe the seventh-day Sabbath (Rev $13: 15){ }^{74}$

\section{"Many Depart the Faith"}

During these events, God's remnant people will be severely tested.

"The time is not far distant when the test will come to every soul. The mark of the beast will be urged upon us. Those who have step by step yielded to worldly demands and conformed to worldly customs will not find it a hard matter to yield to the powers that be, rather than subject themselves to derision, insult, threatened imprisonment, and death. The contest is between the commandments of God and the commandments of men. In this time the gold will be separated from the

73 White, The Great Controversy, 604.

74 White, Testimonies to Ministers and Gospel Workers, 472-73. dross in the church" ${ }^{75}$

In this time "such as never was" (Dan 12:1), the Scriptures must be the anchor for the people of God. "The Bible will never be superseded by miraculous manifestations. The truth must be studied; it must be searched for as hidden treasure. Wonderful illuminations will not be given aside from the Word or to take the place of it. Cling to the Word, receive the engrafted Word which will make men wise unto salvation. ${ }^{76}$ Apparently the counterfeit will resemble the true so closely that only by testing every statement and every miracle by the Holy Scriptures will humanity know what is God's authentic voi$\mathrm{ce}^{77}$

As the date of the death decree approaches, some of the rebellious try to preemptively slay God's people. "But none can pass the mighty guardians stationed about every faithful soul. Some are assailed in their flight from the cities and villages; but the swords raised against them break and fall as powerless as a straw. Others are defended by angels in the form of

75 White, Testimonies for the Church, 5:81.

76 White, Selected Messages, 2:48.

77 White, The Great Controversy, 593. 
men of war" 78

\section{God Breaks into History in a Literal, Visible Second Coming}

And then God delivers His faithful children!

"I saw that God will in a wonderful manner preserve His people through the time of trouble... The decree will go forth that they must disregard the Sabbath of the fourth commandment, and honor the first day, or lose their lives; but they will not yield, and trample under their feet the Sabbath of the Lord, and honor an institution of the papacy. Satan's host and wicked men will surround them, and exult over them, because there will seem to be no way of escape for them. But in the midst of their revelry and triumph, there is heard peal upon peal of the loudest thunder. The heavens have gathered blackness, and are only illuminated by the blazing light, and terrible glory from heaven, as God utters His voice from His holy habitation... the captivity of the righteous is turned, and with sweet and solemn whisperings they say to one another, 'We are delivered. It is

78 Ibíd., 631. the voice of God". 79

Jesus as conquering king and Lord of the Universe descends upon a cloud, wrapped in flaming fire ${ }^{80}$ The wicked call upon the rocks and mountains to hide them from the face of the One whose love they have rejected (Rev 6:16). With no Sun or Shield to protect them (Ps 84:11), the rebellious are destroyed by the extraordinary brightness of His coming (2Thess 2:8) while the righteous cry in utter delight, "Lo, this is our God: we have waited for Him, and He will save us" (Isa 25:9).

"Amid the reeling of the earth, the flash of lightning, and the roar of thunder, the voice of the Son of God calls forth the sleeping saints. He looks upon the graves of the righteous, then, raising His hands to heaven, $\mathrm{He}$ cries: 'Awake, awake, awake, ye that sleep in the dust, and arise!' Through the length and breadth of the earth the dead shall hear that voice, and they that hear shall live. And the whole earth shall ring with the tread of the exceeding great army of every nation, kindred, tongue, and people. From the prison house of death

79 White, Testimonies for the Church, 1:353-54.

80 White, The Great Controversy, 640-41. 
they come, clothed with immortal glory, crying: 'O death, where is thy sting? $\mathrm{O}$ grave, where is thy victory?' 1 Corinthians 15:55". ${ }^{81}$

\section{The Millenium}

Ascending to heaven with Christ and the hosts of heavenly beings (1Thess 4:16-17), the righteous with perfect joy explore the wonders of heaven for 1000 years, while Satan and his parasites are confined to the desolate wasteland of earth. At the close of the thousand years, Jesus again returns to the earth, along with the host of the redeemed and a retinue of angels. ${ }^{82}$ "Then the wicked will be raised from the dead and appear before God for the execution of the "judgment written" (Rev 20:5; Isa 24:22). Enraged to see the righteous safe inside the resplendent city walls, Satan tries to rally his minions to overtake the city (Rev 20:7-8). ${ }^{83}$ "Now Christ again appears to the view of His enemies... The power and majesty of Christ no language can describe, no pen portray". ${ }^{84}$

As Jesus opens before the wicked the record of earth history-the

81 Ibíd., 644.

82 Ibíd., 662.

83 Ibíd., 661.

84 Ibíd., 665. scenes of Adam's temptation and fall, the redemptive work of Christ on earth, and their own myriad opportunities to accept the proffered grace of Christ-the wicked understand what they have forfeited by their life of rebellion. Though all acknowledge the justice and fairness of God, their hatred of Him remains (Rev 15:3). ${ }^{85}$

\section{The Cosmic Conflict Ends; the New Earth Restored}

Fire comes down from heaven and destroys them, Satan the root, his followers the branches (Rev 20:9-10; Mal 4:1). "Satan's work of ruin is forever ended" ${ }^{86}$ "Sin and sinners are no more". 87 "No eternally burning hell will keep before the ransomed the fearful consequences of $\sin " .88$

In contrast with the spiritualized eternity of dualism, God recreates a material Planet Earth, with no more possibility for pain, tears, funerals, sorrow or crying (Nah 1:9). "The great controversy is ended... The entire universe is clean. One pulse of harmony and gladness beats through the vast

85 Ibíd., 666-69.

86 Ibíd., 673.

87 Ibíd., 678.

88 Ibíd., 674. 
creation". 89

Humanity's greatest minds cannot even dimly comprehend the experience of heaven. Even prophetic language is inadequate to describe its wonder and the depth of joy God's redeemed will share in seeing and communing with Christ. "Human language is inadequate to describe the reward of the righteous. It will be known only to those who behold it. No finite mind can comprehend the glory of the paradise of God". 90 "No eye has seen, no ear has heard, and no mind has imagined what God has prepared for those who love him" (1Cor 2:9 NLT).

66 "God's original purpose in the creation of the earth is fulfilled as it is made the eternal home of the ransomed". 91

89 Ibíd., 678.

90 Ibíd., 675.

91 Ibíd., 674.
"The cross of Christ will be the science and the song of the redeemed through all eternity. In Christ glorified they will behold Christ crucified. Never will it be forgotten that $\mathrm{He}$ whose power created and upheld the unnumbered worlds... bore the guilt and shame of sin... The mystery of the cross explains all other mysteries. In the light that streams from Calvary the attributes of God which had filled us with fear and awe appear beautiful and attractive... It will be seen that $\mathrm{He}$ who is infinite in wisdom could devise no plan for our salvation except the sacrifice of His Son. The compensation for this sacrifice is the joy of peopling the earth with ransomed beings, holy, happy, and immortal". ${ }^{92}$

92 Ibíd., 652. 